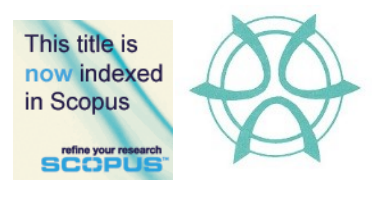

\title{
COVID-19 OUTBREAK AND ROLE OF TOURISM DEVELOPMENT ON ECONOMIC GROWTH IN PAKISTAN
}

\author{
Normah Abdul Latip ${ }^{1}$, Rehmat Karim ${ }^{2}$, Azizan Marzuki ${ }^{3}$, Faqeer Muhammad ${ }^{4}$, \\ Attaullah Shah ${ }^{5}$, Veronica Yilret Nanle ${ }^{6}$, Mohd Umzarulazijo Umar ${ }^{7}$ \\ 1,2,3,4,5,6,7 School of Housing Building and Planning \\ UNIVERSITI SAINS MALAYSIA
}

\begin{abstract}
The current research aimed to find out the effect of tourism development on economic growth in Pakistan for the period (1995 to 2017) by using Canonical Regression Analysis (CCR) and Dynamic Least Square (DOLS) method. In addition, a unit root test is used to find out the static nature of the variables, and for the robust check, the authors utilize the Fully Modified Least Square (FMOLS) method. The results of the CCR and DOLS shows the key role of tourism development on growth, and FMOLS confirms these findings. In addition, the contribution of financial development is insignificant and positive. However, inflation harms economic growth, which depicts that the government of Pakistan will face severe challenges to achieve the targeted level of growth in future. In addition, an outbreak of Coronavirus Disease (Covid-19) is another challenge that will cause a significant decline in tourism receipts.
\end{abstract}

Keywords: Covid-19, Tourism Development, Economic Growth, Pakistan

\footnotetext{
${ }^{1}$ Senior Lecturer at University Sains Malaysia. Email: norma_abdlatip@usm.my
} 
PLANNING MALAYSIA

Journal of the Malaysia Institute of Planners (2021)

\section{INTRODUCTION}

Tourism influences the global economy significantly, and currently, tourism accounts for $10 \%$ of the world's GDP and Jobs (WEF, 2020). Tourism expenditure implies the induction of new cash into the country's economic system (Archer \& Cooper, 1998; Fletcher, 1994), which has a multiplier effect on the host country's economy. The travel and tourism industry has been boosting up at $4 \%$ annually, which is a significantly higher growth rate (WEF, 2015). Tourism has multipliers impact on hotels, wholesalers, restaurants, retail shops, air transport, road transport, labour such as porters, tour guides and hotel managers (Rana, 2015), and it also supports infrastructure development, culture and peace development in a region (Bahuguna, 2005). Tourism can also be counted as an essential element of green economy objectives (UNWTO, 2008). Tourism development increases the income of households, jobs creation in both formal and informal sectors and it also assists the family to come out from the poverty trap and put families on development path (Oh, 2005; Zortuk, 2009). In the rural and mountain regions of the world, tourism is the primary source of households' livelihoods. The flow of tourists in these regions enables the local populace to set up their business and earn their living (Ali and Yousuf 2019; Ali et al., 2017). Such initiative would also lead to women empowerment (Ali et al., 2016). International tourism significantly influences the economic growth of Pakistan (Manzoor et al., 2019; Jalil, Mahmood and Idrees, 2013). Therefore, the objective of the current study is to investigate the relationship between tourism development and economic growth in Pakistan. Moreover, the effects of Covid19 are also highlighted in the study.

\section{LITERATURE REVIEW}

Tourism is one of the world's major economic sectors. It is the third-largest export category after fuels and chemicals in the global economy. For some countries, tourism can represent over $20 \%$ of their GDP. Tourism supports and provides livelihoods for millions of people in developing and developed economies. The flow of tourists to tourists' destinations has been increasing significantly over the last five years owing to improve law and situation and tourism-friendly policies of the current government. In the context of Pakistan, according to World Travel and Tourism Council (2018), in 2017, the direct contribution of travel and tourism to Pakistan economy was PKR 930.9 billion, which is $2.9 \%$ of the total Gross Domestic Product (GDP) 2017. The council forecasted that the share of contribution of travel and tourism to the GDP of Pakistan will increase 5.8\% per annum during the period 2018-2028. In terms of employment generation, travel and tourism directly supported $2.5 \%$ (91.49 million jobs) of the total employment of Pakistan in the year 2017, and it remained 2.8\% in 2018. It has been forecasted 
Normah Abdul Latip, Rehmat Karim, Azizan Marzuki, Faqeer Muhammad, Attaullah Shah, Veronica Yilret Nanle, Mohd Umzarulazijo Umar

Covid-19 Outbreak and Role of Tourism Development on Economic Growth in Pakistan

by 2028 travel and tourism sector will directly generate 2.008 million jobs annually in Pakistan economy.

Figure 1: Trends of Tourism Receipts and GDP in Pakistan
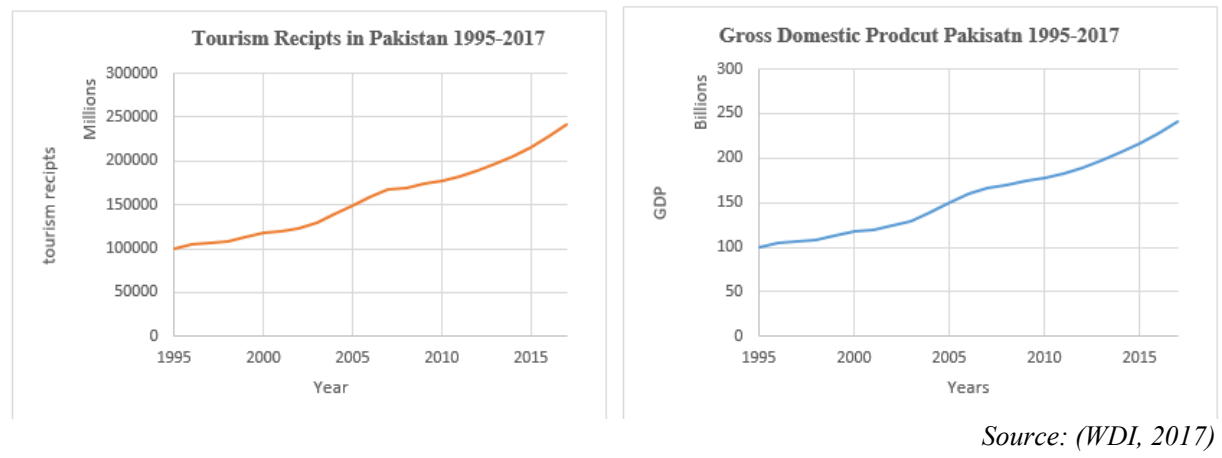

However, the outbreak of Covid-19 worldwide has severely negative consequences on the travel and tourism sector, and this pandemic has created a state of uncertainty in the world economies. The World Travel and Tourism Council (2020) forecasted that the coronavirus pandemic could reduce fifty million jobs worldwide in the tourism and travel sector. It has also warned that Asia is expected to suffer the most. The international travel industry could be negatively impacted by up to $25 \%$ in 2020 , equivalent to the loss of three months of travel. Further, once the COVID-19 pandemic is over, it could take up to ten months to recover the travel and tourism industry. According to UNWTO (2020), a $20 \%$ to $30 \%$ decline in international tourists' arrival is expected in the year 2020 , and this could induce a loss to 300 to 450 USD billion in global tourism receipts. COVID-19 is causing disruptions in imports and exports of Pakistan, which could cause a loss of up to $4.64 \%$ in GDP (PIDE, 2020).

\section{METHODOLOGY}

The study is quantitative; therefore, it used secondary data to determine the relationship between variables. This research investigates the effects and longrun relationship between Pakistan's tourism and economic growth. The proxy for tourism development and growth is a gross domestic product. Similarly, financial development is measured by $\mathrm{m} 2$ as a percentage of GDP. Lastly, the annual consumer price index measures the variable control inflation. The research period is 1995 to 2017, and data is acquired from World Development Indicators (WDI). Initially, the researchers utilized the unit root test for exploring the stationary/non-stationary variables to know the order of the integration. Later, Canonical Cointegrating Regression (CCR) and Dynamic Least Squares (DOLS) are utilized to inspect tourism development's influence on economic growth. 
Lastly, for robustness check, the Fully Modified Least Square Method (FMOLS) is employed and the data is processed in E-Views 10.

The proposed regression model is given below;

$$
\text { growthi, } \mathrm{t}=\beta \mathrm{o}+\beta 1[\text { tourism }] \mathrm{t}+\beta 2[\text { conditioningset }] \mathrm{i}, \mathrm{t}+\text { uit }
$$

Where, inflation (inflat) and financial development (findev) are control variables in the research

$$
\text { growtht }=\mathrm{o}+\text { tourism }+ \text { findev }+ \text { inflat }+
$$

\section{ANALYSIS AND FINDING}

The average of tourism receipts is $20.46 \%$ with a maximum of $20.84 \%$ and the minimum tourism receipt is $20.59 \%$. Similarly, during the study period, the maximum inflation is $20.29 \%$ and the minimum inflation is $2.53 \%$. On the other hand, the probability value of Jarque-Bera is more than 0.05 which shows that variables; growth, tourism, find and inflate are normally distributed (Table 1).

Table 1: Descriptive Statistics

\begin{tabular}{lcccc}
\hline & growth & toursim & findev & inflat \\
\hline Mean & 25.74643 & 20.45748 & 49.80920 & 8.038529 \\
Median & 25.79378 & 20.59430 & 49.86215 & 7.598684 \\
Maximum & 26.20747 & 20.84283 & 58.86769 & 20.28612 \\
Minimum & 25.32990 & 20.01399 & 38.59470 & 2.529328 \\
Std. Dev. & 0.273389 & 0.262787 & 5.356454 & 4.471212 \\
Skewness & 0.008141 & -0.318666 & -0.266924 & 0.845179 \\
Kurtosis & 1.708681 & 1.499624 & 2.478470 & 3.457656 \\
Jarque-Bera & 1.598279 & 2.546599 & 0.533780 & 2.938977 \\
Probability & 0.449716 & 0.279907 & 0.765757 & 0.230043 \\
Sum & 592.1679 & 470.5220 & 1145.612 & \\
Sum Sq. Dev. & 1.644317 & 1.519256 & 631.2151 & \\
Observations & 23 & 23 & & 23 \\
\hline \multicolumn{5}{c}{} \\
\end{tabular}

Canonical Regression Analysis (CCR) shows that tourism receipts have a significant and positive contribution to economic growth in Pakistan which matches the findings of (Jalil, Mahmood, \& Idrees (2013); Adnan Hye \& Khan (2013) and Khalil, Kakar \& Malik (2007). Results revealed that a $1 \%$ increase in tourism receipts enhances growth by $1.02 \%$ in Pakistan, however, the lockdown of the economies around the globe due to Covid-19 significantly reduce the tourism receipts, which would reduce the growth further (Table 2). Moreover, the 
Normah Abdul Latip, Rehmat Karim, Azizan Marzuki, Faqeer Muhammad, Attaullah Shah, Veronica Yilret Nanle, Mohd Umzarulazijo Umar

Covid-19 Outbreak and Role of Tourism Development on Economic Growth in Pakistan

impression of financial development on growth is positive and insignificant. While, inflation is retarding economic growth similar to the studies of (Barro, 1995; Andres \& Hernando, 1997; Stockman, 1981) which indicate that in the upcoming year's government, could not able to achieve the desired growth in Pakistan.

The recent lock has created demand-pull inflation on one hand and the other hand supply pulls inflation is also expected in the economy due to hoarding for-profit motive.

Table 2: Estimation Results

\begin{tabular}{llccccc}
\hline \multicolumn{2}{c}{ Canonical Cointegrating Regression (CCR) } & \multicolumn{2}{c}{ Dynamic Least Squares (DOLS) } \\
Variables & Coefficient & t-Statistic & Prob. & Coefficient & t-Statistic & Prob. \\
\hline \multirow{2}{*}{ toursim } & 1.020357 & 7.164756 & 0.0000 & 0.971283 & 5.306179 & 0.0011 \\
findev & 0.008681 & 1.254267 & 0.2258 & 0.009845 & 1.083376 & 0.3145 \\
inflat & -0.032048 & -5.734382 & 0.0000 & -0.028160 & -3.003997 & 0.0198 \\
\multicolumn{2}{c}{ R-square } & 0.868467 & & 0.988395 \\
\hline \multicolumn{4}{c}{} & \multicolumn{3}{c}{ Source: Authors, 2021 }
\end{tabular}

Similar results are obtained from DOLS, where tourism receipts enhance growth significantly and positively. An increase of $1 \%$ in tourism receipts will increase the growth by $0.97 \%$, which is almost close to the findings of CCR. At the same time, financial development has positive but insignificant, and the influence of inflation on economic growth is positive and significant. The research findings show the long-run association between tourism and growth and contribution of tourism is significant and positive. Similarly to the earlier results, an increase of $1 \%$ in tourism receipts in Pakistan will enhance the economic growth by $1.04 \%$ (Table 3). In line with former studies, inflation is unsuitable for economic growth, which needs to be controlled for long-run growth. Lastly, the effect of financial development is insignificant and positive in contrast to the studies of (Schumpeter 1911; Goldsmith, 1969; Beck \& Levine, 2004; Jalil \& Ma, 2008). The study of (Mhadhbi 2014) also shows the absence of the role of financial development in growth.

Table 3: Robust Analysis

\begin{tabular}{cccc}
\hline Variables & Coefficient & t-Statistic & Prob. \\
\hline toursim & 1.042685 & 7.680174 & 0.0000 \\
findev & 0.006763 & 1.115303 & 0.2794 \\
inflat & -0.030737 & -5.749027 & 0.0000 \\
& R-square & \multicolumn{2}{c}{0.876766} \\
\hline
\end{tabular}




\section{CONCLUSION}

FMOLS method for robustness check is employed, and outcomes of the Canonical Regression Analysis (CCR) reveal the significant impact on economic growth but due to continued lockdown due to Covid outbreak substantially reduced the tourist arrivals in the international market which directly affected the tourism receipts. During the lockdown, all modes of transportation were not in operation; including the domestic flights and international flights, railway service, bus, truck, and vehicles transports, entire educational, business, sports and religious institutions were closed, and human resources working to the tourism and transportation industries were also to face the worst situations. Additionally, since growth is directly related to financial development but inflation in the national economy hinders the overall increase in economic activities, which indicates a problematic situation for the government to maintain a desirable economic growth in Pakistan. Moreover, the Covid case has created demand-pull inflation is predicted in the national economy. Although international tourism badly affected Pakistan, domestic tourism increased significantly in Pakistan, especially in the northern part. As per the government of Gilgit-Baltistan, around 1.379 million domestic tourists visited the northern mountainous region, which becomes almost equal to the population of the entire Gilgit-Baltistan, which needed to be treated as sustainable tourism development.

\section{ACKNOWLEDGEMENTS}

The authors would like to acknowledge Universiti Sains Malaysia for providing the Research University Grants (RU), Grant No: 1001/PPBGN/8016051 as financial support to conduct this research.

\section{REFERENCES}

Ali, A. Ahsan. S., and Dziegielewski F. S. (2017). Social and family capital and youth career intention: A case study in Pakistan. Cogent Business \& Management. 4: 1362838

Ali, A. and Yousuf, S. (2019). Social Capital and Entrepreneurial Intention: Empirical Evidence from Rural Community of Pakistan. Global journal of Entrepreneurship research

Ali, A. Bano, N. and Dziegielewski F. S. (2016). Role of AKRSP on Gender Development: A Case Study in Pakistan, Journal of Social Service Research

Adnan Hye, Q. M., \& Ali Khan, R. E. (2013). Tourism-led growth hypothesis: A case study of Pakistan. Asia Pacific Journal of Tourism Research, 18(4), 303-313.

Andres, J., \& Hernando, I. (1997). Does inflation harm economic growth? Evidence for the OECD. NBER Working Paper No. 6062. Cambridge: National Bureau of Economic Research.

Archer, B., \& Cooper, C. (1998). The positive and negative impacts of tourism. In W. F. Theobald (Ed.), Global tourism (pp. 63-81). Oxford: Butterworth-Heinemann. 
Normah Abdul Latip, Rehmat Karim, Azizan Marzuki, Faqeer Muhammad, Attaullah Shah, Veronica Yilret Nanle, Mohd Umzarulazijo Umar

Covid-19 Outbreak and Role of Tourism Development on Economic Growth in Pakistan

Bahuguna, A. (2005). Tourism in India: A development perspective. The Indian Economic Journal, 39, 38-141.

Barro, R.J., (1995). Inflation and Economic Growth, Bank of England Quarterly Bulletin, $166-176$.

Beck, T., \& Levine, R. (2004). Stocks markets, banks, and growth: Panel evidence. Journal of Banking and Finance, 28, 423-442.

Fletcher, J. (1994). Input-output analysis: Tourism management and marketing handbook. New York, NY: Prentice-Hall.

Goldsmith, R. W. (1969). Financial Structure and Development. New Haven: Yale University Press

Haider, H. (2020). Top story. Retrieved from https://www.thenews.com.pk/print/637732covid-19-economy-may-face-gdp-loss-of-up-to-4-64-percent

Jalil, A., Mahmood, T., \& Idrees, M. (2013). Tourism-growth nexus in Pakistan: Evidence from ARDL bounds tests. Economic Modelling, 35, 185-191.

Jalil, A. \& Ma, Y. (2008). Financial Development on Economic Growth: Time Series Evidence from China and Pakistan. Journal of Economic Cooperation, 29 (2), 29 68

Khalil, S., Kakar, M. K., \& Malik, A. (2007). Role of tourism in economic growth: Empirical evidence from Pakistan economy [with comments]. The Pakistan Development Review, 985-995.

Manzoor, F., Wei, L., Asif, M., Haq, M.Z. and Rehman, H. (2019). The Contribution of Sustainable Tourism to Economic Growth and Employment in Pakistan. Int. J. Environ. Res. Public Health. 16, 3785.

Mhadhbi, K. (2014). A new proxy for financial development and economic growth: What Causes What? Bootstrap panel causality for 21 low-income countries. International Journal of Research in Business Management, 2 (5), 11-24

Oh, C. O. (2005). The contribution of tourism development to economic growth in the Korean economy. Tourism Management, 26(1), 39-44.

Rana, A. R. (2015). Promotion of tourism in Pakistan. Pakistan Institute of Legislative Development and Transparency, Islamabad, Pakistan.

Schumpeter, J. A. (1911). The Theory of Economic Development. Harvard University Press.

Stockman, A. C. (1981). Anticipated inflation and the capital stock in a cash-in-advance economy. Journal of Monetary Economics, 8, 387-393.

UNWTO (2008). United Nations World Tourism Organization. Tourism satellite account: A recommended methodological framework.

UNWTO (2020). United Nations World Tourism Organization Impact assessment of the COVID-19 outbreak on International Tourism. Retrieved from

https://www.unwto.org/impact-assessment-of-the-covid-19-outbreak-on international tourism?

World Economic Forum. (2015). The travel \& tourism competitiveness report, 2015. Geneva: Author.

World Travel and Tourism Council (2018). Travel \& Tourism Economic Impact 2018 Pakistan. Retrieved from https://www.wttc.org//media/files/reports/economicimpact research/archived/countries-2018/pakistan2018.pdf 
PLANNING MALAYSIA

Journal of the Malaysia Institute of Planners (2021)

World Economic Forum (2020). Retrieved from https://www.weforum.org/agenda/2020/03/world-travel-coronavirus-covid19jobs-pandemic-tourism-aviation/

Zortuk, M. (2009). The economic impact of tourism on Turkey's economy: Evidence from cointegration tests. International Research Journal of Finance and Economics, 25(3), 231-239.

Received: $5^{\text {th }}$ November 2021. Accepted: $5^{\text {th }}$ December 2021 